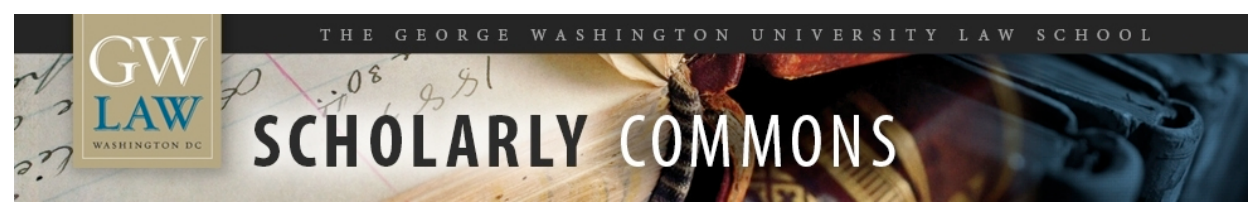

\title{
Mandatory Disclosure: A Case Study in How Anti-Corruption Measures Can Affect Competition in Defense Markets
}

Christopher R. Yukins

George Washington University Law School, cyukins@law.gwu.edu

Follow this and additional works at: https://scholarship.law.gwu.edu/faculty_publications

Part of the Law Commons

\section{Recommended Citation}

Yukins, Christopher R., Mandatory Disclosure: A Case Study in How Anti-Corruption Measures Can Affect Competition in Defense Markets (April 16, 2015). GWU Law School Public Law Research Paper No.

2015-14; A paper presented at the conference, "Ethical Dilemmas in the Global Defense Industry," Center for Ethics and the Rule of Law, University of Pennsylvania Law School, April 16, 2015.; GWU Legal Studies Research Paper No. 2015-14; GWU Law School Public Law Research Paper No. 2015-14. Available at SSRN: http://papers.ssrn.com/sol3/papers.cfm?abstract_id=2600676

This Article is brought to you for free and open access by the Faculty Scholarship at Scholarly Commons. It has been accepted for inclusion in GW Law Faculty Publications \& Other Works by an authorized administrator of Scholarly Commons. For more information, please contact spagel@law.gwu.edu. 


\section{THE GEORGE WASHINGTON UN IVERS I T LAW SCHOOL}

GW Law School Public Law and Legal Theory Paper No. 2015-14

GW Legal Studies Research Paper No. 2015-14

Mandatory Disclosure: A Case Study in How AntiCorruption Measures Can Affect Competition in Defense Markets

Christopher R. Yukins

A paper presented at the conference, "Ethical Dilemmas in the Global Defense Industry,"

Center for Ethics and the Rule of Law, University of Pennsylvania Law School, April 16, 2015.

This paper can be downloaded free of charge from the Social SCIENCE RESEARCH NETwORK: http://ssrn.com/abstract=2600676 


\title{
Mandatory Disclosure: A Case Study in How Anti-Corruption Measures Can Affect Competition in Defense Markets
}

\author{
Christopher R. Yukins
}

\author{
Lynn David Research Professor in Government Procurement Law and \\ Co-Director, Government Procurement Law Program, \\ The George Washington University Law School
}

A paper presented at the conference,

"Ethical Dilemmas in the Global Defense Industry,"

Center for Ethics and the Rule of Law, University of Pennsylvania Law School

April 16, 2015

\begin{abstract}
In the U.S. defense procurement market, regulators require contractors to make "mandatory disclosures" if principals at those firms determine, after due review, that there is credible evidence that the firms engaged in certain crimes (fraud, bribery or gratuities), civil fraud, or significant overpayment by the government. Failure to make such a mandatory disclosure, required by clause and by regulation, can lead to (among other things) the debarment of the contractor -- a potentially devastating result. Mandatory disclosure is a natural extension of a separate requirement, that contractors maintain effective corporate compliance and ethics systems, and the Defense Department's largest prime contractors, with sophisticated compliance systems in place, have been able to accommodate the mandatory disclosure requirement. This paper asks whether this disclosure requirement in effect favors those largest contractors, and decreases competition in a already highly concentrated defense market, either by creating substantial legal risks for firms too small or inexperienced to institute effective compliance and disclosure systems, or by discouraging competition from other companies in the commercial sector. The paper concludes that the mandatory disclosure rule can impair competition in defense procurement, and recommends that regulators carefully shape any disclosure requirements, and perhaps reconsider relying on voluntary disclosure, mindful of the need to reduce costs and enhance competition in defense procurement markets.
\end{abstract}

\section{Introduction}

In U.S. defense contracting, an increasingly important tool in fighting corruption is "mandatory disclosure" -- the requirement that when managers at a contracting firm discover that the firm has been engaged in certain wrongdoing, they must disclose that wrongdoing to the government. ${ }^{1}$ Mandatory disclosure plays an especially prominent role in defense contracting,

\footnotetext{
${ }^{1}$ The clause at Federal Acquisition Regulation (FAR) 52.203-13, 48 C.F.R. § 52.203-13, Contractor Code of Business Ethics and Conduct, requires that a contractor, as part of its system of internal controls, make:
} 


\section{Mandatory Disclosure: A Case Study in How Anti-Corruption Measures Can Affect Competition in Defense Markets, by Christopher R. Yukins, GWU Law School}

both because of the relative size of the defense spending in overall federal procurement, and because a handful of very large prime contractors, with extraordinarily strong compliance and disclosure systems, dominate the U.S. defense marketplace. In part because those large contractors set a high norm for disclosure, which other contractors have difficulty matching, ${ }^{2}$ the U.S. defense market raises an interesting quandary: does mandatory disclosure, an important anti-corruption tool, in effect dampen competition in a procurement market?

This brief paper addresses that question in several steps. Part II of the paper reviews the history of mandatory disclosure in federal contracting, and explains how mandatory disclosure is tied to broader compliance requirements in U.S. contracting. Part III discusses some of the anticompetitive effects of mandatory disclosure, and Part IV assesses possible remedies. Part V concludes by suggesting that mandatory disclosure, like other anti-corruption efforts, should be carefully structured to reduce its negative effects on competition.

Footnote continued from previous page

(F) Timely disclosure, in writing, to the agency OIG [Office of Inspector General], with a copy to the Contracting Officer, whenever, in connection with the award, performance, or closeout of any Government contract performed by the Contractor or a subcontractor thereunder, the Contractor has credible evidence that a principal, employee, agent or subcontractor of the Contractor has committed a violation of Federal criminal law involving fraud, conflict of interest, bribery, or gratuity violations found in Title 18 U.S.C. or a violation of the civil False Claims Act (31 U.S.C. 3729-3733).

Under FAR 9.406-2(b)(vi), 48 C.F.R. § 9.406-2(b)(vi), Causes for Debarment, a debarring official may debar a contractor, based upon a preponderance of the evidence, for:

Knowing failure by a principal, until 3 years after final payment on any Government contract awarded to the contractor, to timely disclose to the Government, in connection with the award, performance, or closeout of the contract or a subcontract thereunder, credible evidence of-

(A) Violation of Federal criminal law involving fraud, conflict of interest, bribery, or gratuity violations found in Title 18 of the United States Code;

(B) Violation of the civil False Claims Act (31 U.S.C. 3729-3733); or

(C) Significant overpayment(s) on the contract, other than overpayments resulting from contract financing payments ....

${ }^{2}$ See, e.g., Jessica Tillipman \& Vijaya Surampudi, The Compliance Mentoring Program: Improving Ethics and Compliance in Small Government Contractors (Apr. 2015) (paper presented at conference "Ethical Dilemmas in the Global Defense Industry"), to be made available on www.ssrn.com.

Page 2

DRAFT 23 APRIL 2015 


\section{Mandatory Disclosure: A Case Study in How Anti-Corruption Measures Can Affect Competition in Defense Markets, by Christopher R. Yukins, GWU Law School}

\section{Mandatory Disclosure -- Background}

Mandatory disclosure in federal contracting grew out of two separate initiatives: an effort to find a replacement for voluntary disclosures (which had largely failed in defense contracting), and a broader effort to establish compliance systems for federal contractors. ${ }^{3}$

The predecessor to mandatory disclosure -- the Voluntary Disclosure Program -- was launched by the federal government in July $1986,{ }^{4}$ shortly before the "Illwind" procurement scandals which swept up many major defense contractors. ${ }^{5}$ The Voluntary Disclosure Program reflected an attempt to formalize, and thus open to a broader set of contractors, a practice of informal, voluntary disclosures which the major defense contractors were already making. ${ }^{6}$

Voluntary disclosure under the formal program was a very cumbersome process, with uncertain benefits for those that made disclosures; the Justice Department, the Defense Department and other enforcement entities retained substantial discretion to decide what impact, if any, a voluntary disclosure would have on a contractor's eventual punishment, and voluntary disclosure risked triggering additional liability from whistleblowers (or "relators") under the federal False Claims Act. ${ }^{7}$ The Voluntary Disclosure Program declined in popularity. When the mandatory disclosure rule was proposed at the Justice Department's request in 2007, therefore, the Justice Department's core goal was to replace the fraud and corruption cases which were no longer emerging through the Voluntary Disclosure Program. ${ }^{8}$

\footnotetext{
${ }^{3}$ For a widely respected monograph on the contractor compliance and mandatory disclosure requirements, see Guide to the Mandatory Disclosure Rule: Issues, Guidelines, and Best Practices (Frederic M. Levy \& Robert F. Huffman, eds., American Bar Association 2010).

${ }^{4}$ See, e.g., Inspector General, U.S. Department of Defense, The Department of Defense Voluntary Disclosure Program: A Description of the Process (Apr. 1990), available at http://www.dodig.mil/iginformation/archives/vdguidelines.pdf.

${ }^{5}$ See, e.g., Timothy M. Cox, Is the Procurement Integrity Act "Important" Enough for the Mandatory Disclosure Rule? A Case for Inclusion, 40 Pub. Cont. L.J. 347, 371-74 (2011); In re Search Warrant for Secretarial Area Outside Office of Gunn, 855 F.2d 569, 570 (8th Cir. 1988) (discussing broad "Illwind" investigation disclosed by search warrants executed on over 40 locations on June 14, 1988).

${ }^{6}$ See Letter of Deputy Secretary of Defense William H. Taft, IV, July 24, 1986 ("a number of major Defense contractors have adopted a policy of voluntarily disclosing problems affecting their corporate contractual relationship with the Department of Defense"), reproduced in The Department of Defense Voluntary Disclosure Program: A Description of the Process, supra note 4, App. A.

${ }^{7}$ See generally Robert S. Ryland, The Government Contractor's Dilemma: Voluntary Disclosures As the Source of Qui Tam Litigation, 22 Pub. Cont. L.J. 764 (1993).

872 Fed. Reg. 64019, 64020 (Nov. 14, 2007) ("According to DoJ, the requirement for mandatory disclosure is necessary because few companies have actually responded to the invitation of DoD that they report or voluntarily disclose suspected instance of violations of Federal criminal law relating to the contract or subcontract.”).
}

Page 3

DRAFT 23 APRIL 2015 


\section{Mandatory Disclosure: A Case Study in How Anti-Corruption Measures Can Affect Competition in Defense Markets, by Christopher R. Yukins, GWU Law School}

It should be stressed, however, that when the proposed rule requiring mandatory disclosure rule was published in November 2007, it came as something of a surprise to the federal contracting community. ${ }^{9}$ The Federal Acquisition Regulation (FAR) councils had earlier published a proposed rule, in February 2007, which addressed contractor compliance requirements alone, and built on earlier, agency-specific requirements for such compliance systems. ${ }^{10}$ The compliance systems requirement was not a surprise; as many commentators outside the government had noted, corporate compliance systems were already called for by the U.S. Sentencing Commission's organizational sentencing guidelines, and so extending those requirements to contractors was a predictable next step. ${ }^{11}$ In response to the request from the Justice Department, however, the FAR councils in November 2007 published a broader proposed rule, which called for both contractor compliance systems and mandatory disclosure. ${ }^{12}$ The mandatory disclosure requirement became part of the final combined rule in November 2008, and that final rule took effect on December $12,2008 .^{13}$

While it applied to contracts awarded by all agencies (not just the Defense Department), the new mandatory disclosure rule drew on many elements of the prior voluntary disclosure program. Disclosures under the mandatory compliance rule are typically to be processed through the contracting officer, who is to coordinate a response with the agency inspector general. ${ }^{14} \mathrm{As}$ with the voluntary disclosure program, disclosures and enforcement are to turn on whether there is "credible evidence" of a bad act. ${ }^{15}$ The mandatory disclosure rule calls for disclosures of specific bad acts, and the new rule leaves it to the contractor, after due investigation (potentially under an attorney-client privilege), to determine in the first instance whether there is credible evidence of the enumerated bad acts. The mandatory disclosure rule notably does not require disclosure of other, non-enumerated forms of bad acts, such as violations of the Procurement Integrity Act -- even though that law was born of the same procurement scandals which emerged alongside the voluntary disclosure rule. ${ }^{16}$

\footnotetext{
${ }^{9}$ For a discussion of how the mandatory disclosure rule emerged in the government's rulemaking process, see, for example, Brian D. Miller, The Federal Acquisition Regulation Mandatory Disclosure Rule Program at the U.S. General Services Administration Office of Inspector General, at 2-4 (updated June 2012), available at http://www.gsaig.gov; see also Guide to the Mandatory Disclosure Rule, supra note 3, at 9-10 (history of rule). 


\section{Mandatory Disclosure: A Case Study in How Anti-Corruption Measures Can Affect Competition in Defense Markets, by Christopher R. Yukins, GWU Law School}

The mandatory disclosure rule, unlike its predecessor, does not explicitly incentivize disclosure; a contractor will not necessarily win a reduced sentence by making a mandatory disclosure. But if a contractor fails to make a mandatory disclosure -- i.e., if a contractor's principals have credible evidence of an enumerated bad act and the contractor fails to disclose that information -- the contractor may be suspended or debarred, on that ground alone. ${ }^{17}$

It is important to stress how mandatory disclosure is intertwined with the corporate compliance requirements, which were made part of the same rule. The mandatory disclosure rule assumes that a contractor's compliance system will survey for, and detect, bad acts, and that those bad acts were will be reported up through the firm so that the bad acts can be assessed and then, as appropriate, reported to the government. ${ }^{18}$ The mandatory disclosure rule thus arguably rests on an assumption that contractors will have an effective compliance system in place. ${ }^{19}$

Experience under the mandatory disclosure rule has been mixed. While some contractors have tried to mitigate risk by reporting many possible violations to the government -- from petty to major violations -- other contractors have reportedly taken a much narrower approach to disclosure under the rule. ${ }^{20}$ What is clear, however, is that mandatory disclosure is taken very seriously by mature defense contractors, including, especially, the handful of large prime contractors at the core of the defense market, and that those contractors cognizant of the requirement take careful steps to integrate disclosure into their broader compliance efforts. ${ }^{21}$

The mandatory disclosure requirements for contractors also can be read against the backdrop of disclosures required of publicly traded companies, under the securities law reforms enacted in the early 1930s. The mandatory disclosures required by those laws were intended to

\footnotetext{
${ }^{17}$ Applicable regulations are set forth in footnote 1, supra. The standards for potential suspension parallel those for debarment, which are set forth in the footnote.

${ }^{18}$ See, e.g., Guide to the Mandatory Disclosure Rule, supra note 3, at 97-113 (discussing techniques for ensuring adverse information regarding bad acts is "reported up" through the firm).

${ }^{19}$ See id. at 97.

${ }^{20}$ See, e.g., David Robbins, Embracing Mandatory Disclosure Can Save Contractors Time, Trouble and Legal Fees, National Defense, June 2014, available at

http://www.nationaldefensemagazine.org/archive/2014/June/Pages/EmbracingMandatoryDisclosureCanSaveContrac torsTime,TroubleandLegalFees.aspx; Dietrich Knauth, Contractors Overload Agencies by Reporting Smallest Frauds, Law360, Apr. 20, 2012, available at http://www.law360.com/articles/326078/contractors-overloadagencies-by-reporting-smallest-frauds-?article_related_content $=1$.

${ }^{21}$ For a practical discussion of the tactical concerns that drive contractors' disclosure decisions, see Frederic Levy \& Todd Canni, McKenna Long \& Aldridge, Suspension or Debarment: Are They in Your Future? Government Contractor Compliance Risk Areas for 2013, available at https://www.mckennalong.com/publications-advisories3211.html.
}

Page 5

DRAFT 23 APRIL 2015 
reshape the balance of power between shareholders and managers in publicly traded firms, by forcing managers to open corporate governance by broadening shareholders' access to information. These disclosure requirements under the securities laws were born of unique cultural, historical and political circumstances in the United States, which favored disclosure to support the common investor in the wake of the financial crash of $1929 .^{22}$

Viewed in this light, the mandatory disclosure requirements under the FAR can be seen as an analogous effort to redraw the agency relationship, not between managers and shareholders, but instead between the government and its contractors. ${ }^{23}$ There is a natural asymmetry of information between the government and its contractors, which opens the door for strategic behavior -- including, potentially, fraudulent and corrupt behavior -- by the contractors. By forcing mandatory disclosure of information on bad acts, the government has broken down that asymmetrical relationship, at least in part.

This leads, in turn, to a number of important questions. Why, for example, did the government choose these bad acts -- why not require disclosure, for example, of all production failures (even if they do not constitute fraud), or of violations of other important anti-corruption measures, such as the Procurement Integrity Act, the Anti-Kickback Act or the covenant against contingent fees? More broadly for our purposes here, how and why does this system of mandatory disclosure affect competition in procurement markets (most specifically, the defense market), and what can be done to ease its potentially anticompetitive effects?

\section{Anti-Competitive Effects of Mandatory Disclosure}

As noted, changes to the securities laws of the 1930s forced new mandatory disclosures in financial markets, in order to radically reshape agency relationships between management and shareholders, by reducing the informational advantage that managers held. In contrast, as was described above, the mandatory disclosure rule imposed on contractors in 2008 was arguably an evolutionary measure, which did not reorder but instead reinforced existing competitive advantages held by the Defense Department's largest contractors, and bolstered existing reputational bonds between the Defense Department and those large firms. This section assesses those practical effects of the mandatory disclosure rule, and their potentially anti-competitive effects.

\section{A. Mandatory Disclosures Depend on Effective Compliance Systems -- Which the Largest Contractors Have Been Building for Decades}

\footnotetext{
${ }^{22}$ See, e.g., James A. Fanto, The Absence of Cross-Cultural Communication: SEC Mandatory Disclosure and Foreign Corporate Governance, 17 Nw. J. Int'l L. \& Bus. 119, 137-39 (1996) (citing Paul G. Mahoney, Mandatory Disclosure As A Solution to Agency Problems, 62 U. Chi. L. Rev. 1047 (1995)).

${ }^{23}$ See generally Christopher R. Yukins, A Versatile Prism: Assessing Procurement Law Through the PrincipalAgent Model, 40 Pub. Cont. L.J. 63 (2010), http://ssrn.com/abstract=1776295.
}

Page 6

DRAFT 23 APRIL 2015 


\section{Mandatory Disclosure: A Case Study in How Anti-Corruption Measures Can Affect Competition in Defense Markets, by Christopher R. Yukins, GWU Law School}

To understand mandatory disclosure's potential anti-competitive effect, it is important to stress that mandatory disclosure depends, first, on an effective compliance system. Without an effective compliance system, information on apparent violations -- the stuff of mandatory disclosures -- typically will not "bubble up" to management's attention, except by accident. Put another way, without an effective compliance system in place, a contractor runs material risk of not being able to meet its mandatory disclosure obligation if, indeed, the firm engages in one of the prohibited acts (criminal or civil fraud, bribery, etc.).

The standards for compliance systems are remarkably uniform across borders, ${ }^{24}$ both inside and outside procurement markets. ${ }^{25}$ As the following chart illustrates, countries and standards-setting organizations across the world require the same basic elements -- including a code of conduct, training, etc. -- in corporate compliance systems:

\footnotetext{
${ }^{24}$ For different perspectives on these common international standards, see, for example, Thomas Fox, What Are the Essential Elements of a Corporate Compliance Program? (May 23, 2013), available at http://www.lexisnexis.com/legalnewsroom/corporate/b/fcpa-compliance/archive/2013/05/23/what-are-the-essentialelements-of-a-corporate-compliance-program.aspx (discussing presentation of Paul McNulty \& Stephen Martin, Baker \& McKenzie).

${ }^{25}$ For a description of how to structure an effective ethics program within a defense contractor, see Defense Industry Initiative, Creating and Maintaining an Effective Ethics and Business Conduct Program, available at http://www.dii.org/system/files_force/dii-toolkit.pdf?download=1.
}

Page 7

DRAFT 23 APRIL 2015 


\begin{tabular}{|l|l|l|l|l|l|}
\hline \multicolumn{6}{|c|}{ CORPORATE COMPLIANCE: INTERNATIONAL } \\
\hline $\begin{array}{l}\text { EARMOnts of } \\
\text { Corporate } \\
\text { Compliance } \\
\text { Systems }\end{array}$ & $\begin{array}{l}\text { U.S. } \\
\text { Sentencing } \\
\text { Commission: } \\
\text { Organizational } \\
\text { Sentencing } \\
\text { Guidelines }\end{array}$ & $\begin{array}{l}\text { U.S. Federal } \\
\text { Acquisition } \\
\text { Regulation } \\
\text { (FAR): } \\
\text { Contractor } \\
\text { Compliance } \\
\text { Requirements }\end{array}$ & $\begin{array}{l}\text { UK Ministry } \\
\text { of Justice: } \\
\text { Compliance } \\
\text { Under UK } \\
\text { Bribery Act }\end{array}$ & $\begin{array}{l}\text { Organisation } \\
\text { for } \\
\text { Economic } \\
\text { Cooperation } \\
\& \\
\text { Development } \\
\text { (OECD) }\end{array}$ & $\begin{array}{l}\text { International } \\
\text { Chamber of } \\
\text { Commerce } \\
\text { (ICC) }\end{array}$ \\
\hline $\begin{array}{l}\text { Standards and } \\
\text { procedures }\end{array}$ & $\sqrt{ }$ & $\sqrt{ }$ & $\sqrt{ }$ & $\sqrt{ }$ & $\sqrt{ }$ \\
\hline $\begin{array}{l}\text { Knowledgeable } \\
\text { leadership }\end{array}$ & $\sqrt{ }$ & $\sqrt{ }$ & $\sqrt{ }$ & $\sqrt{ }$ & $\sqrt{ }$ \\
\hline $\begin{array}{l}\text { Exclude risky } \\
\text { personnel }\end{array}$ & $\sqrt{ }$ & $\sqrt{ }$ & $\sqrt{ }$ & $\sqrt{ }$ & $\sqrt{ }$ \\
\hline Training & $\sqrt{ }$ & $\sqrt{ }$ & $\sqrt{ }$ & $\sqrt{ }$ & $\sqrt{ }$ \\
\hline $\begin{array}{l}\text { Monitor, } \\
\text { evaluate, } \\
\text { reporting } \\
\text { hotline }\end{array}$ & $\sqrt{ }$ & $\sqrt{ }$ & $\sqrt{ }$ & $\sqrt{ }$ \\
\hline $\begin{array}{l}\text { Incentives and } \\
\text { discipline }\end{array}$ & $\sqrt{ }$ & $\sqrt{ }$ & $\sqrt{ }$ & $\sqrt{ }$ \\
\hline $\begin{array}{l}\text { Adjust } \\
\text { program to risk }\end{array}$ & $\sqrt{ }$ & & & $\sqrt{ }$ \\
\hline
\end{tabular}

Although these harmonized standards mean that multinational firms bear lower costs of compliance across borders, the costs of establishing and maintaining an effective compliance and ethics system (however uniform) should not be underestimated. ${ }^{26}$

Though corporate compliance systems were first mandated in federal contracting in 2008, major contractors began to implement compliance systems (also known as corporate integrity

\footnotetext{
${ }^{26}$ See, e.g., Stacey English \& Susannah Hammond, Cost of Compliance 2014 Survey (Thomson Reuters Accelus), available at http://accelus.thomsonreuters.com/sites/default/files/GRC00814.pdf. For an interesting alternative viewpoint, on how small businesses can establish ethics and compliance systems at almost no cost, see Joseph E. Murphy, A Compliance \& Ethics Program on a Dollar a Day: How Small Companies Can Have Effective Programs (Aug. 2010), available at http://www.corporatecompliance.org/Portals/1/PDF/Resources/CEProgramDollarADayMurphy.pdf.
} 


\section{Mandatory Disclosure: A Case Study in How Anti-Corruption Measures Can Affect Competition in Defense Markets, by Christopher R. Yukins, GWU Law School}

systems) many years earlier, driven in important part by the defense industry's corruption scandals (laid bare by the Justice Department's "Illwind" investigation) of the 1980s. ${ }^{27}$ The large contractors that had embraced corporate compliance and ethics programs therefore were well-prepared for the compliance requirements mandated by regulation in 2008, and for the mandatory disclosure requirements that flowed from those compliance requirements. As a practical matter, however, it is widely believed in the federal procurement community that hundreds, if not thousands, of small- and medium-sized defense contractors did not have (and do not have) effective compliance and ethics systems in place, and thus cannot readily meet the mandatory disclosure requirements of the law. ${ }^{28}$

The risks of not having an effective compliance system are magnified by the unique antifraud/anti-corruption laws governing federal contracting -- many of which trigger the mandatory disclosure rule. For example, when the rule requires disclosure of any violation of "Federal criminal law involving fraud, conflict of interest, bribery or gratuity violations found in Title 18 of the United States Code," this sweeps up personal conflicts of interest under 18 U.S.C. $\S 208$, which can be highly technical and difficult to detect, with no de minimis exception ${ }^{29}$ but with a complex set of regulatory safe harbors. ${ }^{30}$ Nor are the civil fraud requirements easy to meet:

\footnotetext{
${ }^{27}$ See, e.g., Nancy B. Kurland, The Defense Industry Initiative: Ethics, Self-Regulation, and Accountability, 12 J. Bus. Ethics 137 (1993). A later report summarized the evolving efforts, through these years, to build compliance programs in the defense industry:
}

Large U.S. companies engaged as defense contractors with various branches of the U.S. military continued to be accused of fraudulent practices spawning federal government demands for a more comprehensive ethics and compliance program by many U.S. corporations. These firms revised their code of ethics, created employee ethics training programs and established internal processes for auditing employee practices, particularly with regards to pricing of products to the government. Many of these ethics and compliance program revisions or improvements were in response to the threats by the federal government to terminate all contracts in the future if changes were not made ....

James Weber \& David M. Wasieleski, Corporate Ethics and Compliance Programs: A Report, Analysis and Critique, 112 J. Bus. Ethics Business Ethics 609, 611 (2012).

${ }^{28}$ Although contractors working under smaller contracts (under $\$ 5$ million) are technically exempt from the compliance system requirements of the contract clause at FAR 52.203-13, see FAR 3.1004(a), 48 C.F.R. § 3.1004(a), if a contractor under such a small contract (typically a small business) fails to disclose the covered bad acts (including fraud and corruption), under FAR Subpart 9.4, that contractor risks potential suspension or debarment. In other words, while contractors on smaller procurements bear risk because they must disclose certain bad acts, under the terms of the rule itself those businesses may well not have a compliance system in place to screen for and identify those bad acts.

${ }^{29}$ See U.S. Office of Governmentwide Ethics, 18 U.S.C. $\S 208$ : Acts Affecting a Personal Financial Interest, http://www.oge.gov/Laws-and-Regulations/Statutes/18-U-S-C--\%C2\%A7-208--Acts-affecting-a-personal-financialinterest/ ("The criminal prohibition has no de minimis level. That is, it applies where any financial interest exists, no matter how small.”).

${ }^{30} 5$ C.F.R. Part 2640.

Page 9

DRAFT 23 APRIL 2015 


\section{Mandatory Disclosure: A Case Study in How Anti-Corruption Measures Can Affect Competition in Defense Markets, by Christopher R. Yukins, GWU Law School}

whereas common law fraud normally requires intentional fraud to trigger liability ${ }^{31}$ under the federal false claims act mere recklessness is enough. ${ }^{32}$ Thus, a firm's aggressive recruiting of retiring government employees (which can be criminal under 18 U.S.C. $§ 208$ ), ${ }^{33}$ or sloppy accounting or production methods (which can constitute reckless fraud), all may trigger liability, and thus an obligation to report under the mandatory disclosure rule. This means, in turn, that a firm without an effective compliance system in place -- a firm, in other words, in the mass of unprepared defense contractors -- is left exposed to potentially disastrous risks, both of substantive violations and of failing to make the mandated disclosure of those violations. In sum, the mandatory disclosure rule exacerbates the competitive disadvantages borne by smalland medium-sized enterprises which have been too slow to adopt corporate compliance systems.

\section{B. Mandatory Disclosure Reinforces Reputational Bonds Between Contractors and the Defense Department}

As the discussion above reflects, mandatory disclosure amplifies the competitive weaknesses borne by the many contractors -- potentially thousands of firms -- in the middle and lower tiers of the defense marketplace which do not have effective compliance systems. The mandatory disclosure rule hurts those small- and mid-sized firms in another way: only the largest firms, with effective and highly public compliance and disclosure systems, can assure the Defense Department that the reputational capital which those firms share with the government will be carefully protected, through internal enforcement and disclosure.

The U.S. defense industry has become much more concentrated over recent decades, ${ }^{34}$ and now a handful of prime contractors dominate that market. ${ }^{35}$ While previous studies have suggested that sophisticated contractors may structure themselves to reduce reputational risk to the government and the contractors, ${ }^{36}$ there has been little, if any, specific assessment of the

\footnotetext{
31 See, e.g., Strategic Diversity, Inc. v. Alchemix Corp., 666 F.3d 1197, 1210 n.3 (9th Cir. 2012).

${ }^{32}$ See, e.g., Claire M. Sylvia, The False Claims Act: Fraud Against the Government $\$ 4: 38$ (2014) (discussing authorities applying recklessness standard under False Claims Act).
}

${ }^{33}$ See, e.g., Former Boeing Exec Pleads to Conspiracy Charge, 18 Andrews Gov't Cont. Litig. Rep. 7 (2004).

${ }^{34}$ See, e.g., F.G. Hayden, Elliot G. Campbell, and Shannon Cummins, The Ranking of Contractors to the U.S. Department of Defense According to Integrated Power Blocs Among the Contractors, 44 J. Econ. Issues 411, 412414 (2010) (recent history of consolidation in defense history).

${ }^{35}$ See, e.g., Erik Kopač, Defense Industry Restructuring: Trends in European and U.S. Defense Companies, _Transition Studs. Rev. _ (2006).

${ }^{36}$ One study, by Chong Wang of the Naval Postgraduate School, suggested that the largest, most politically connected contractors may hire politically astute senior retirees from the military establishment so as to curb the contractor's own opportunistic (corrupt or rent-seeking) behavior that would undermine the government's reputation. See, e.g., Chong Wang, Political Connections of the Boards of Directors and Department of Defense Contractors' Excessive Profits, 14 J. Pub. Proc. 96, 113 (2014) ("DoD contractors may hire . . politically connected directors and use their experience to serve a benevolent role to the public. For instance, one legitimate use of the 


\section{Mandatory Disclosure: A Case Study in How Anti-Corruption Measures Can Affect Competition in Defense Markets, by Christopher R. Yukins, GWU Law School}

mandatory disclosure rule's role in this complex relationship between the Defense Department and its largest contractors.

The starting point for this discussion is a recognition that a government inevitably shares reputational capital with its contractors, especially those prime contractors under its direct control. ${ }^{37}$ The debate over private military contractors, for example, has highlighted that shared reputational capital, for those arguing for tighter regulation of PMCs have pointed out that the contractors' actions can impair a government's reputation and legitimacy. ${ }^{38}$

Viewed in this light, the mandatory disclosure rule may be seen as a capstone on a broader government effort to force contractors, through ethics and compliance programs, to control the risks of fraud and corruption -- especially reputational risks -- on behalf of the government. The mandatory disclosure rule notably does not focus on performance risks; there is no requirement, for example, to report new obstacles which may slow a project. ${ }^{39}$ Instead, as written and implemented, the mandatory disclosure rule serves more as an early warning device for fraud and corruption, to alert the government to potential egregious violations by contractors. ${ }^{40}$ While contractors are expected to identify and initially investigate the violations, ultimate enforcement against those violations still rests with the government. From officials' perspective, the government leverages the contractors' compliance and ethics system to gain better visibility into violations, thus multiplying the government's enforcement capacity and --

Footnote continued from previous page

political experience is to keep DoD contractors from opportunistic profit-seeking behaviors that could reach or even cross federal government regulatory redlines.")

${ }^{37}$ See, e.g., Douglas P. Beighle, Defense Contractors - The Next Spotted Owl?, 24 Nat. Cont. Man. J. 1 (1991) (discussing Congress' and contractors' shared reputational loss due to negative studies and procurement scandals of the previous decade).

${ }^{38}$ See, e.g., Zoe Salzman, Private Military Contractors and the Taint of a Mercenary Reputation,40 N.Y.U. J. Int'1 L. \& Pol. 853 (2007-2008). A study of the use of military law to address contractor criminal misconduct in combat areas pointed out that "[c]ontractor criminal activity can generate significant media interest, adversely impact strategic relationships with host nation governments, and require commanders to swiftly formulate a response when such incidents occur within their areas of operation." Lieutenant Colonel Charles T. Kirchmaier, Command Authority over Contractors Serving With or Accompanying the Force, 439 Army Law., Dec. 1, 2009, 35, 37; Nigel D. White \& Sorcha MacLeod, EU Operations and Private Military Contractors: Issues of Corporate and Institutional Responsibility, 19 Eur. J. Int'1 L. 965 (2008).

${ }^{39}$ Disclosure of those performance-based risks are typically dealt with separately, under contractual clauses which require, for example, that contractors report any extraordinary costs which may be chargeable to the government within 30 days.

${ }^{40}$ Guidance by the then-Inspector General for the General Services Administration, for example, explained that contractors should give early notification, even before an investigation is concluded, and that the agency would normally await conclusion of the contractor's investigation before taking any action. Brian D. Miller, supra note 9, at 10 ("We prefer early notification, and so long as the contractor keeps us informed of its progress, we do not intervene until the contractor has completed its internal review."). 


\section{Mandatory Disclosure: A Case Study in How Anti-Corruption Measures Can Affect Competition in Defense Markets, by Christopher R. Yukins, GWU Law School}

importantly -- sharply reducing reputational risks from otherwise unpredictable and uncontrolled third-party reports of fraud and corruption, for example from the press and whistleblowers.

In practice, however, this mandatory disclosure model appears to be one which favors large, established contractors, and which in effect bolsters barriers to entry in the defense market. The mandatory disclosure requirements are themselves idiosyncratic -- some crimes are subject to mandatory disclosure, but many are not -- and so demand time and sophistication to integrate into a broader compliance and ethics program. That foundation underlying mandatory disclosure, an effective compliance and ethics program, is also extremely expensive, and while some of those compliance costs may be allowable under cost-reimbursement contracts, a compliance program inevitably causes additional costs (including opportunity costs) which will not be absorbed by the government customer.

Nor do the costs end once mandatory disclosure has been integrated into an ethics and compliance program. The compliance system must remain active, gathering, processing and assessing reports of possible violations. When violations may call for mandatory disclosure, those possible violations must be specially assessed, often with input from sophisticated outside counsel. The contractor may undertake an internal investigation, under the protection of an attorney-client privilege, and the contractor ultimately need only disclose those circumstances which present "credible evidence" of an enumerated bad act (bribery, fraud, etc.). Mandatory disclosure is, in other words, a long, costly process, one built on an already expensive system of ethics and compliance -- not a process that favors those new to the market, or short of resources. Mandatory disclosure is, in sum, a rule which can be readily implemented by large, established contractors, but which poses daunting obstacles to those contemplating entering the defense market, and which poses serious risks to competitors that cannot (or care not to) implement it properly.

\section{Easing the Anti-Competitive Effects of Mandatory Disclosure}

As the discussion above reflects, the mandatory disclosure rule creates substantial benefits for enforcement officials (by unearthing violations for enforcement) and, more broadly, for the government as a whole by reducing the costs and reputational risks of fraud and corruption. At the same time, though, the mandatory disclosure rule creates significant costs for contractors, and tends to favor the largest, most deeply established contractors in the market. In a defense market that is already markedly concentrated, those anti-competitive forces are a cause for concern. This section assesses possible ways to ease the rule's inherently anti-competitive effects. ${ }^{41}$

\footnotetext{
${ }^{41}$ For a general discussion of the legal and policy imperatives for assessing procurement rules' potentially anticompetitive effects, see Christopher R. Yukins \& Lt. Col. Jose Cora, Feature Comment: Considering the Effects of Public Procurement Regulations on Competitive Markets, 55 Gov. Contractor II 64 (Mar. 6, 2013), available at http://ssrn.com/abstract=2230613.
} 


\section{A. Governments Should Facilitate Compliance and Ethics Systems}

One obvious measure to enhance competition would be to reduce contractors' costs of administering the corporate compliance and ethics system upon which the mandatory disclosure requirement rests. This can be done, for example, by making model codes of ethics and training freely publicly available, and by using common standards for compliance systems. ${ }^{42}$ The important point is one of perspective: in mandating compliance systems among their contractors, governments should recognize that the goal is a one of reducing agency costs -- to ensure that the government's rules and principles are conveyed, and complied with, efficiently down through the supply chain. Doing so will reduce hiccups in the supply chain, and will expand the available competition. Viewed in this way, the government has every incentive to cooperate fully with its vendors, large and small, in establishing robust and effective compliance systems.

\section{B. Harmonize Standards for Mandatory Disclosure}

Governments' success in harmonizing the standards for compliance systems (discussed above) should be matched in mandatory disclosure requirements: to the extent a government decides to mandate disclosures, those requirements should be harmonized across regulatory regimes. Thus, for example, it makes little sense for the federal government to require:

- Federal contractors to make mandatory disclosures once they have credible evidence of enumerated crimes (bribery or gratuity under Title 18, U.S. Code), civil or criminal fraud under the False Claims Act, or "significant overpayments," while requiring,

- Federal grantees to make mandatory disclosures of, "in a timely manner, in writing to the Federal awarding agency or pass-through entity all violations of

\footnotetext{
${ }^{42}$ Rather than simply adopt the organizational compliance standards promulgated by the U.S. Sentencing Commission -- a sister federal agency, which maintains what are commonly referred to as the "gold standard" for corporate compliance standards, see, e.g., Paul E. McGreal, The Amended Organizational Sentencing Guidelines: Top Ten Things Attorneys Should Know, The Houston Lawyer, March/April 2005, available at http://www.thehoustonlawyer.com/aa_mar05/page10.htm -- the drafters of the federal procurement rules insisted on creating their own, parallel standards. 73 Fed. Reg. at 67068. Because the FAR compliance standards are largely, but not perfectly, identical to the U.S. Sentencing Commission guidelines (see chart above), the FAR regulators' insistence on drafting their own standards increased contractors' implementation costs, and may mean that the federal procurement standards will lag a step behind, as the U.S. Sentencing Commission's guidelines evolve over time.
} 


\section{Mandatory Disclosure: A Case Study in How Anti-Corruption Measures Can Affect Competition in Defense Markets, by Christopher R. Yukins, GWU Law School}

Federal criminal law involving fraud, bribery, or gratuity violations potentially affecting the Federal award." 43

Thus, while contractors must disclose both criminal (intentional) and civil (reckless) fraud, the covered grantees need only disclose criminal fraud; by the same token, it is not clear what other criminal statutes are covered in the grantees' requirements (is the Anti-Kickback Act, for example, a "Federal criminal law involving . . . bribery"?). There is no ready reason for these standards to differ, especially since federal contractors regularly serve as grantees, as well, ${ }^{44}$ and the federal grant rule was explicitly modeled on the contract mandatory disclosure rule. ${ }^{45}$ Where, as here, mandatory disclosure requirements vary -- apparently unnecessarily -- private vendors must spend more to implement these varying standards, and other potential competitors are further discouraged from competing for federal contracts or grants.

\section{Limit Scope: Target Violations for Which Contractors Have a Clear Informational Advantage, or Which Pose Most Severe Reputational Risks}

Because of the costs and potentially anti-competitive effects of mandatory disclosure, ${ }^{46}$ it is important that the scope of mandatory disclosure be carefully limited. In principle, because (as noted) regulators' goals here should be to level the informational imbalance between government and its contractors, and to force early (and controlled) disclosures of violations which pose potentially severe reputational risk, logically regulators should craft the mandatory disclosure rule to force disclosure of bad acts:

- For which contractors enjoy a clear informational advantage, and

- Which pose the sharpest reputational risks to the government.

\footnotetext{
${ }^{43}$ Section 200.113 of the Office of Management \& Budget's "Super Circular" governing federal grants (now known as the "Omni Circular"), 78 Fed. Reg. 78590 (Dec. 26, 2013), which is being implemented by federal grantmaking agencies, provides as follows:

$\$ 200.113$ Mandatory disclosures. The non-Federal entity or applicant for a Federal award must disclose, in a timely manner, in writing to the Federal awarding agency or pass-through entity all violations of Federal criminal law involving fraud, bribery, or gratuity violations potentially affecting the Federal award. Failure to make required disclosures can result in any of the remedies described in $\S 200.338$ Remedies for noncompliance, including suspension or debarment. (See also 2 CFR Part 180 and 31 U.S.C. 3321)

${ }^{44}$ Data on federal funds received by grantees and contractors are available in a combined database, through www.USASpending.gov.

${ }^{45}$ See 78 Fed. Reg. at 78595.

${ }^{46}$ Mandatory disclosure also may implicate broader issues of self-incrimination; these are potentially human rights issues, beyond the scope of this paper, which focuses instead on the economic costs and benefits of a mandatory disclosure regime. See, e.g., Jeremy A. Goldman, Note, New Far Rule on Compliance Programs and Ethics: A Hidden Assault on the Corporate Attorney-Client Privilege, 39 Pub. Cont. L.J. 71 (2009).
} 


\section{Mandatory Disclosure: A Case Study in How Anti-Corruption Measures Can Affect Competition in Defense Markets, by Christopher R. Yukins, GWU Law School}

Although the federal mandatory disclosure rule apparently was not crafted with these goals in mind -- instead, it appeared to reflect various enforcement agencies' efforts to include specific bad acts onto the mandatory disclosure list ${ }^{47}$-- the final rule does, in rough terms, reflect these dual goals. The bad acts which must be disclosed are generally those which contractors have an easier time discerning than the government (e.g., bribes, gratuities and fraud), and, again because of complicated reasons of agency, ${ }^{48}$ these are precisely the bad acts which are most likely to have deeply corrosive reputational impacts on the government. In other words, although the federal rule is not perfect, ${ }^{49}$ it does appear to accommodate these dual policy goals.

\section{Allow Contractor Opportunity to Investigate, Under Privilege}

Another, relatively simple means of reducing the anti-competitive impact of a mandatory disclosure rule is to allow the contractor time, before making any disclosure, to assess the evidence under the protection of a privileged investigation. ${ }^{50}$ The drafters of the federal rule prudently, and explicitly, decided to leave contractors this breathing space before making a mandatory disclosure. ${ }^{51}$ Although critics may argue that the rule thus allows contractors time to "bury" troubling evidence, the alternative -- to require contractors to disclose any apparent violation, without due investigation -- would be highly inefficient. A rule demanding immediate disclosure could mean that the government would be flooded with reports which might prove, in the end, to be groundless. Furthermore, a rule which forced immediate disclosure of any bad act brought to light in a compliance system would, in effect, encourage contractors not to have

\footnotetext{
${ }^{47}$ For a detailed discussion of this aspect of the administrative history of the mandatory disclosure rule, see, e.g., Brian D. Miller, supra note 9, at 3-5.

${ }^{48}$ See, e.g., Susan Rose-Ackerman, The Law and Economics of Bribery and Extortion, 6 Ann. Rev. L. \& Soc. Sci. 217, 218 (2010) ("Principal-agent relationships are at the heart of any corrupt transaction. An employee or another person acting as an agent for a government body or a private organization accepts a private benefit in return for acting in the payee's interest."); Nico Groenendijk, A Principal-Agent Model of Corruption, 27.3-4 Crime, L. \& Soc. Change 207 (1997).

${ }^{49}$ The federal rule's open-ended requirement that contractors disclose "significant overpayments" remains uncertain. The provision also may be exploited by contractors which seek to make some disclosure, to comply with the rule, but not to report more serious bad acts (such as fraud); these contractors instead may simply disclose a "significant overpayment," pending a more detailed internal review. See Brian D. Miller, supra note 9, at 10.
}

\footnotetext{
${ }^{50}$ See generally, Guide to the Mandatory Disclosure Rule, supra note 3, ch. 10 (on preserving confidentiality and privilege during an investigation).

${ }^{51}$ See, e.g., 73 Fed. Reg. at 67074 (“[T]he [FAR] Councils believe that using the standard of 'credible evidence' ... will help clarify 'timely' because it implies that the contractor will have the opportunity to take some time for preliminary examination of the evidence to determine its credibility before deciding to disclose to the Government. Until the contractor has determined the evidence to be credible, there can be no 'knowing failure to timely disclose.' This does not impose upon the contractor an obligation to carry out a complex investigation, but only to take reasonable steps that the contractor considers sufficient to determine that the evidence is credible.").
} 


\section{Mandatory Disclosure: A Case Study in How Anti-Corruption Measures Can Affect Competition in Defense Markets, by Christopher R. Yukins, GWU Law School}

effective corporate compliance systems, but instead to allow news of bad acts to drift into dark silence at the bottom of the firm.

\section{E. Reinvigorate Voluntary Disclosure}

The final proposed change to the mandatory disclosure regime may be the most radical, but the most useful: to recognize that mandatory disclosure will probably always be limited (for the reasons outlined above), so that the optimal policy choice instead may be to reinvigorate voluntary disclosure, by giving contractors positive incentives, perhaps through reduced enforcement penalties, to come forward with bad acts. ${ }^{52}$

A voluntary disclosure regime, unlike a mandatory one, could cover a much broader array of bad acts and crimes, for it would pose none of the risks (discussed above) that an overbroad mandatory regime carries, of inefficiently forcing disclosures of too many bad acts. A system of voluntary disclosure would reduce the costs of implementation, because a voluntary regime means that only those contractors that discover bad acts internally, and seek to make a voluntary disclosure to reduce their exposure, must study and abide by the voluntary disclosure rules. Finally, a voluntary disclosure regime would have a much less damaging effect on competition, for contractors that could not manage disclosure -- the contractors at serious peril in a mandatory regime -- would face no new risks of destruction in a voluntary regime; failing to make a disclosure would simply lose them the leniency they might otherwise enjoy, under a voluntary regime.

As noted, several decades ago the federal government instituted a system of voluntary disclosure to handle fraud in defense procurement, a system which failed largely because of its own cumbersomeness, and because it did not present defense contractors with sufficient incentives for disclosure. A renewed emphasis on voluntary disclosure, perhaps with clearer and stronger incentives for disclosure, and potentially modeled on the World Bank's reportedly successful system of voluntary disclosures for contractors ${ }^{53}$ might prove a useful way forward.

\footnotetext{
${ }^{52}$ As Susan Rose-Ackerman noted, in discussing the importance of whistleblowing in addressing corruption:
}

Successful detection of corruption depends upon insiders to report wrongdoing. Citizens and businesses victimized by extortion demands may report bribery attempts, but they may not be able to offer enough proof for prosecutors to act. Instead, effective law enforcement often requires officials to promise leniency to one of the participants. This creates an important paradox for law enforcement efforts. High expected punishments ought to deter corruption, but a high probability of detection may only be possible if some are promised low penalties.

Susan Rose-Ackerman, supra note 48, at 222.

\footnotetext{
${ }^{53}$ The World Bank publishes extensive materials on its Voluntary Disclosure Program, which incentivizes contractors on World Bank-funded projects to come forward with information on bad acts, to reduce or avoid the Footnote continued on next page
} 
In assessing a new voluntary disclosure system, though, policymakers might wish to weigh the increasingly important role that whistleblowers (often current or former employees) play in revealing fraud and corruption; a system of voluntary contractor disclosure should complement, not disrupt, existing systems to encourage and protect private whistleblowers.

\section{Conclusion}

The federal government's mandatory disclosure rule provides an interesting case study in how an anti-corruption tool, of good intent, can be quite costly and have anti-competitive effects in an already highly concentrated defense procurement market. To address those problems, a mandatory disclosure rule should be crafted to minimize transaction and opportunity costs, and to focus on the problems at the core of a disclosure rule: the need to remedy the government's informational deficits regarding its contractors' bad acts, to redress fraud and corruption and the reputational damage they can cause the government. Recognizing these broader benefits of disclosure, and the inherent limitations of mandatory disclosure, policymakers may wish to revisit the benefits of incentivizing voluntary disclosures by contractors, as a complement to the information on bad acts gained through mandatory disclosures and whistleblowers.

\footnotetext{
Footnote continued from previous page

risk of sanctions (including potentially debarment) under the World Bank's sanctions system. See, e.g., World Bank, VDP Guidelines for Participants (2011), http://siteresources.worldbank.org/INTVOLDISPRO/Resources/VDP_Guidelines_2011.pdf; World Bank, "About the VDP," http://go.worldbank.org/3JOFMN95S0.
}

\section{Page 17}

DRAFT 23 APRIL 2015 